[Penultimate Draft. Please cite PUblished Version:

Becoming Someone New: Essays on Transformative Experience, Choice, and Change, Enoch Lambert \& John Schwenkler (eds.), Oxford University Press]

\title{
Transformative Expression
}

\author{
Nick Riggle \\ University of San Diego
}

\begin{abstract}
The hope that art could be personally or socially transformational is an important part of art history and contemporary art practice. In the twentieth century, it shaped a movement away from traditional media in an effort to make social life a medium. Artists imagined and created participatory situations designed to facilitate potentially transformative expression in those who engaged with the works. This chapter develops the concept of "transformative expression," and illustrates how it informs a diverse range of such works. Understanding these artworks in this way raises two interesting questions, one about the nature of aesthetic value and the other about the nature of action. Answers to these questions lie in understanding the social and aesthetic character of our capacity to distance ourselves from our commitments and act in the expressive, playful, spontaneous, or imaginative ways that participatory art invites.
\end{abstract}

\section{Introduction}

It's common sense that art can change our lives and selves: novels, poems, films, plays, music, operas - they affect us in profound and transformative ways. Artists needn't intend to have such an effect on their audience; they aim to produce something of value, something worthy. But it turns out that aesthetic value is like that; it has that power. It can change us. ${ }^{1}$

${ }^{1}$ I discuss the transformative power of beauty in Riggle (2016). For a discussion of morally transformative art, see Walden (2015). 
Art can change our lives, but can it be designed to do so directly? ${ }^{2}$ Must we visit a museum to look at grand and expensive paintings, or can art confront and change us in the course of everyday life? If so, then how far can we go? Can we change not only individual lives, but communities or even entire societies? Many twentieth-century artists answered these questions in the affirmative, and their affirmation found expression in a vast range of ingenious and ambitious postwar, postmodern, and contemporary works: "The most radical theses of the European avantgarde during the revolutionary upheavals of 1910-1925: that art must cease to be a specialized and imaginary transformation of the world and become the real transformation of lived experience itself" (Clark et al. n.d.). Over the following century these "radical theses" informed a range of inventive and ambitious works that aim to directly engage people in the course of their lives and move them to express themselves in transformative ways.

But there is a whiff of paradox about this aim. How can we express ourselves in a way that transforms the self we express? We tend to think that a person engages in authentic, or exemplary self-expressive, action only when the action issues from, speaks to, or otherwise embodies their core commitments. A necessary condition of such expressive action, the thought goes, is that it must be expressive of a self—one's true, authoritative, or authentic self-

${ }^{2}$ My focus here is on a specific tradition in European and Anglo-American art (and various movements around the globe influenced by or responding to these traditions), but it is important to note that in some aesthetic traditions the answer is an obvious "yes." Consider this passage from Robert Carter: "The practice of a Japanese art is in all respects transformative. Each art is designed to make one a different person, a better person" (2008: 4). I'll be interested in what follows in how exactly transformative art is supposed to make us "better." Thanks to Julianne Chung for calling my attention to this passage. For more on the topic, see Chung (2018). 
embodied in the preferences, rules, beliefs, desires, or values that the person "owns" and that issue, motivate, or endorse the action. And the action is more authentic the more central to the self those values are. ${ }^{3}$ Such a view is suggested by Sartre's example of the waiter whose actions issue from his sense of what a "waiter" should do but without any substantial commitment to being a waiter. Sartre claims that such a person is acting in "bad faith" precisely because he is not acting from an accurate, or even any, sense of who or what he is. Likewise, when we are forced to act a certain way by social or professional norms, bad jobs, peer pressure, tradition, and so on, we often think we aren't acting well, precisely because our actions fail to express our plans and values, what we really care about, or who we really are. Some philosophers extend such a necessary condition beyond authenticity to autonomy. Your actions are not self-governed, according to such views, unless they embody your plans, the rules or values you endorse, your commitments and concerns, and so on. ${ }^{4}$

More generally, philosophers select some privileged set of dispositions - acting on one's cherished values, higher-order desires, plans, moral convictions, weightiest reasons, etc. - and say that one's actions are authentic or autonomous only if they express or issue from these dispositions. Call this family of theories disposition-centered theories of self-expression:

If A's $\varphi$-ing is authentic/autonomous, then A's $\varphi$-ing expresses A's [self-constituting dispositions].

But if self-expression is an achievement that is the expression of self-constituting dispositions, then how could expressing oneself change those dispositions? The question is especially pressing

\footnotetext{
${ }^{3}$ A classic statement of such a view is Frankfurt (1971).

${ }^{4}$ For discussion of the relation between authenticity and autonomy, see Oshana (2007).
} 
when the relevant action is one the transformed agent would have rejected, would not have endorsed, desired, sought out, or performed, prior to the effect it has on that very agent. Yet that is precisely what is envisioned by so many avant-garde artists who sought to dislodge or replace

people's core commitments in a way that they would embrace. The participants in these artworks would seem to be expressing a self they neither have nor want by way of adopting a new one. How could an artwork do that, even in theory?

In what follows I develop the concept of "transformative expression" and argue that: (1) transformatively expressive acts feature in a range of avant-garde artworks that confound standard ways of thinking about aesthetic value, and (2) they are counterexamples to dispositioncentered theories. These two points turn out to be related: expanding our understanding of aesthetic value to include a range of "playful" actions shows how we can express ourselves even when we are not expressing our commitments. If this is right, then standard theories of aesthetic value and common ways of thinking about authenticity and autonomy should be rejected for the same reason. I sketch better ways of thinking about both.

\section{Defining Transformative Expression}

We can begin to see a problem with the standard way of thinking about self-expression by considering ways of coping when, for one reason or another, we cannot act on our plans, values, or commitments. There was a solid several months in my recent past when I wasn't myself. I hadn't stopped existing, entirely, but I was on the academic job market. I was teaching too much at a small liberal arts college in a cold place with few friends around, uncertain prospects, and no discernible desire to continue. I found myself in a kitchen cooking. A lot. Elaborate fish dinners for midweek lunch, various things pickled or preserved, and so many kinds of squash. Did I 
really want to do this? I think I would have preferred to be wholeheartedly engaged in philosophical activity - the activity around which many of my core values and desires revolved. I wondered, Who does this? Who cooks meals like this for lunch on a Wednesday? Bored chefs maybe. Not me. But it seemed like the thing to do, or at least $a$ thing to do, when the thing to do could not really be done.

Sometimes we do things without being able to relate what we are doing to our normal sense of self—because we are lost, depressed, exploring, ambivalent, curious, desperate, or just compelled to do something - and sometimes expressing some self or other in this way is enough to transform us into some self or other. I now consider myself a pretty good cook.

The exploration of cooking was suggested to me, in part, by the absurd amount of shows I was watching on the Food Network and the Cooking Channel. Restaurant Impossible, hosted by Robert Irvine, is about redesigning restaurant interiors, often on a strict budget. The Restaurant Impossible design team puts together some impressive designs, but they usually aren't very original - many of the motifs, themes, and much of the furniture is seen all over the United States, very likely in the same towns and cities as the featured restaurant. No doubt the restaurant owners have seen and ignored, or maybe even dismissed, such designs. Yet almost without fail (it's a TV show, after all), when the owners see their redesigned space full of these mostly familiar design elements, they break down in tears of amazement, joy, and deep gratitude. They see themselves anew in these designs and their lives as restaurant owners are changed.

People on “makeover" shows like TLC's What Not to Wear or Netflix's Queer Eye have a similar reaction when they get a new haircut and a few new outfits - hairstyles and outfits that they no doubt have seen multiple times, maybe even worn once or twice, and likely rejected as 
something they would never wear. But when they turn around and look in the mirror and at their friends, they seem to be transformed. ${ }^{5}$

Let's call these events "transformative expressions" because they are expressive acts that transform the individual. Here's a way to make the idea I have in mind more explicit. For a person $\mathrm{N}$, an action-type $\mathrm{A}$, and a time interval $t$, N's doing A during $t$ is transformatively expressive if

(1) Prior to $t$ : $\varphi$-type action is not endorsed by N's core commitments.

(2) After $t, \varphi$-ing expresses N's core commitments.

(3) (2) is a direct result of N's $\varphi$-ing during $t$.

Apply this to a makeover case. At and prior to getting the makeover, Dagny does not want to change her personal style - she's committed to it, decidedly happy with her ' 80 s haircut and shoulder-padded blazers. After the makeover, Dagny very much wants to style herself that way - so much so that it seems to her to be one of the more meaningful things she can regularly do for herself. And this is a direct result of acting in a way that is contrary to her sense of self and style. She wouldn't feel this way unless she took the plunge and tried a new look.

The interval $t$ might be short and involve one performance of $\varphi$-type action, but it might be extended across repeated performances of $\varphi$-type action. Someone who dislikes church might

${ }^{5}$ There are other intuitive examples: A person in therapy might express her feelings or voice judgments, and in doing so come to own those feelings or judgments in a transformative way. The emerging literature on games and practical reason emphasizes how games facilitate our trying on different deliberative perspectives and elicit experiences of freedom in potentially transformative ways. See Nguyen (forthcoming); see also Gingerich (2018). 
think it's their only option (perhaps they're persuaded by Pascal's Wager). They go through the motions of attending church every Sunday_-singing the songs, participating in the prayers, listening attentively to the sermons - and after an interval of attendance, going to church is expressive of their core commitments. (The example also shows that $\varphi$-type action, e.g. going to church, can consist in multiple action-types.)

We can imagine a case where (1) and (2) are true but not (3). Imagine that Dagny's new style is not a result of her adopting a new look but rather a result of a new dress code at work that requires proper business attire. She adopts the way of dressing in order to conform to work standards and not be fired; over time, and for reasons other than her conforming to the dress code, she personally changes — she becomes more of a team player, more confident, more organized. Now her core commitments are compatible with, and even expressed through, dressing in proper business attire, but not as a direct result of her (even repeatedly) adopting an unfamiliar look. So dressing that way is not a transformative expression.

I don't mean anything too fancy by the vague notion of a core commitment. A "commitment" here is a stand-in for a range of attitudes. I might be committed to a person because I deeply admire him; I might be committed to a certain artwork because I have a meaningful attachment to it; I might be committed against cucumbers because I really dislike them. A core commitment is one that has a certain importance for the person and is a matter of degree. What makes a commitment core is that it partly constitutes one's individuality-our core commitments are a large part of what makes us what we are like, guiding what we do with our lives and how we do it: what we value, appreciate, avoid, or seek out; the social roles we identify with; the kinds of people we want to be around. A core commitment is such that losing it would 
require us to redraw how we think about who we are and what we care about. ${ }^{6}$ And we might do that a fair amount over time-I don't assume that our core commitments answer to or pick out a "true" self or a fixed self. I have various "commitments" that are not core: I avoid cucumbers, prefer not to bowl (because no matter how hard I try I'm really bad at it), and am reliably down to go on a nice long walk. Changes in these preferences would not change my individuality or threaten my sense of self. Sometimes we do things that are incompatible with our peripheral commitments. I'll throw some cucumbers on a sandwich even though I don't really like them. Maybe one day I'll think, "You know, cucumbers aren't so bad after all.” This isn't transformative because the commitment isn't core. I've simply changed some of my peripheral but reliable preferences.

On this way of construing things, the action mustn't be endorsed by N's core commitments. The comedic Parks and Recreation character Ron Swanson-a passionately pro-America, antigovernment libertarian—regards going to Europe as incompatible with his core commitments. When he finally goes to London, he's basically vindicated. But then his awesome friend Leslie Knope arranges for him to visit the Lagavulin distillery— his favorite whisky — and he realizes that places in Europe really do satisfy his core commitments. This is not a transformative expression so much as a kind of awakening. Ron's commitments don't change, but he's

\footnotetext{
${ }^{6}$ My notion of "core commitment" is the basically the same as Chesire Calhoun's (2009) notion of a "substantive commitment" except "core" is alliterative and only has one syllable. Calhoun writes, "The commitments I have in mind are ones whose objects are candidates for inclusion in a life plan, or that give shape to a life, or define an identity, or answer the question of what one's life is about. Intuitively, sexual, ethnic, and religious identities, place of geographic residence, avocations and careers, and friendships and intimate relationships would count as such candidates" (2009, p. 614).
} 
awakened to a wider world in which they can be exercised. (Note that it's not quite right to say that he has a new core preference for visiting Europe. Perhaps he does in a sense, but only insofar as it speaks to his unchanged commitment to Lagavulin whisky.) Of course, transformative expressions do not always transform you into a better person.

So what is the relation between transformative expression and transformative experience? L. A. Paul (2014) focuses on transformative experiences that are both "epistemically" and "personally" transformative (p. 17). An epistemically transformative experience introduces you to a new phenomenal content - the taste of amaranth, the sound of a steel tongue drum. A personally transformative experience substantially changes your point of view, either by changing your core preferences (p. 16) or how you experience being who you are (p. 16). But paradigmatic transformative experiences in this sense are not transformative expressions in the sense defined here. Consider becoming a parent. For many prospective parents, being a parent is endorsed by their core commitments, so condition (1) of the definition of transformative expression is not met. For many prospective parents, becoming a parent is something they really want, something they hope and prepare for, even if they don't really know what they are going to get. Same goes with becoming a doctor, learning to play the violin, deciding to receive a cochlear implant, or many other aspirations that interact with our core commitments. Another difference between transformative experience and expression concerns the fact that transformative expressions might not be epistemically transformative experiences, when they do not involve a new phenomenal content. Nothing in conditions (1)-(3) require that new phenomenal contents play a role, though they often do. However, as we will see in more detail in the following section, transformative expressions change either the content or order of our core commitments and so are personally transformative experiences. 


\section{Participatory Art}

We can broaden the notion of transformative expression to one of transformative action by modifying (2) and replacing "expresses" with "is endorsed by." So what does expression add to action in the definition? I might really hate doing the dishes, but after doing them time and again and further appreciating the result of a clean kitchen, doing the dishes might be accommodated by my core commitments. But doing the dishes is still not expressive of who I am as an individual. Various job requirements, duties, practical necessities, personal accommodations, and the like have this feature. Transformative expression has a particular value that transformative action lacks. The idea of a transformative expression is that the action expresses some feature of a self that the person did not have before performing it - and that by or through acting, the person comes to realize that the action or something it expresses or embodies is so significant to her as to be self- or life-affirming.

It is this value, I want to argue, that is sought out in a significant tradition of avant-garde art. Much of the rhetoric of the twentieth-century avant-garde concerns transformation. Artists sought to change "subjects," transform "perceptions" or "consciousness," change lives, or transform or "sculpt" society. And to do this they focused much of their creative effort on direct engagement with individuals, constructing "situations," social "interventions," or "happenings" that encouraged the audience to transformatively express themselves: Dada, Futurism, Surrealism, Situationist International, Happenings, Joseph Beuys's “social sculpture," and the more recent work in "relational aesthetics," "social practice," or "participatory art."

Consider this passage from Situationist International co-founder Guy Debord:

The really experimental direction of situationist activity consists in setting up, on the basis of more or less clearly recognized desires, a temporary field of activity 
favorable to these desires. This alone can lead to the further clarification of these simple basic desires, and to the confused emergence of new desires whose material roots will be precisely the new reality engendered by situationist constructions. (2006b [1958]: 49)

Debord defined a "situation" as a "concrete construction of momentary ambiances of life," sites of often playful interaction that spoke to "recognized desires." But these situations were designed to appeal to and unmask those desires in order to ground "new desires" that only a transformed society or "new reality" would satisfy — thus creating a collective desire for this new society.

To this end the situationists envisioned various activities meant to interfere with a person's routines and habits and encourage them to embrace a more playful and passionate way of life. "The goal of the situationists is immediate participation in a passionate abundance of life by means of deliberately arranged variations of ephemeral moments" (Debord 2006c [1958]: 53). The situationists envisioned bringing people together and intervening in the gathering to create a more free, playful, game-like atmosphere. They hoped that doing so would allow us to find ourselves, to construct what the situationists called "real individuals" (Debord 2006b [1958]: p. 51) and to focus our creative and playful activity on our own authenticity and community rather than on a material culture that merely entertains, alienates, and divides. "The point is to produce ourselves rather than things that enslave us" (Debord 2006c [1958]: 53).

The situationists are explicit about the interpersonal character of "producing ourselves"; it requires aesthetic attention to shared space and directed intervention:

If we imagine a particular situation project in which, for example, a research team has arranged an emotionally moving gathering of a few people for an evening, we would no doubt have to distinguish: a director or producer responsible for 
coordinating the basic elements necessary for the construction of the décor and for working out certain interventions in the events. (Debord 2006b [1958]: 50)

For the situationists, self-production is a kind of co-production because selves must be playful, expressive, and open, and they conceive of such action as paradigmatically communal.

We can make some of these ideas more concrete by looking at how social intervention and "producing ourselves" is present in the work of conceptual artist and philosopher Adrian Piper. Piper is a light-skinned black woman who is often assumed to be white. As a result, she frequently found herself among white people who thought she was "one of us" and so would be receptive to their racist conversations and attempts at humor. When she would respond by explicitly calling out the racist or alerting people to her racial identity in advance, she would be perceived as "pushy, manipulative, or socially inappropriate." So she developed an alternative response by intervening in the social dynamics in a way that invites a transformative expression. When someone engaged with, or in, racist talk she would hand out a card that reads:

Dear Friend, I am black.

I am sure you did not realize this when you made/laughed at/agreed with that racist remark. In the past, I have attempted to alert white people to my racial identity in advance. Unfortunately, this invariably causes them to react to me as pushy, manipulative, or socially inappropriate. Therefore, my policy is to assume that white people do not make these remarks, even when they believe there are no black people present, and to distribute this card when they do.

I regret any discomfort my presence is causing you, just as I am sure you regret the discomfort your racism is causing me. 
Sincerely Yours, Adrian Margaret Smith Piper ${ }^{7}$

Piper's title for this work—which she calls "reactive guerrilla performance" — is "My Calling (Card) \#1." Putting the word "Card" in parentheses draws attention to the fact that this is a calling, and Piper nicely draws on the ambiguity of that word. To "call" on someone is ambiguous between a moral demand and a hopeful plea. Piper's social interventions are more than a calling out; they are a calling for. They shift the social dynamics and prime, indeed invite or call on, the recipients to act in ways that could be transformatively expressive. Receiving a personal and unexpected note is intriguing, mysterious. Piper's design ensures that the first thing one notices after receiving a "gift" is that one is being addressed as a "friend," but one who is invited to reflect on their actions. Piper's intervention gives the friend an opportunity to disavow or distance themselves from what they have done. ${ }^{9}$

This nicely fits the scheme of transformative expression: Prior to Piper's intervention, laughing at racist jokes is compatible with their identity. Maybe they don't have a commitment to being openly racist, but they might have a commitment to expressing solidarity with people of their own race through humor, or perhaps to using collective laughter to reinforce social bonds, even at the expense of marginalized groups. So disavowing racist jokes is not endorsed by their core commitments. If Piper's intervention is successful and they disavow their actions, then they are in a position to change their core commitments. For some participants, once might be

\footnotetext{
${ }^{7}$ For a nuanced discussion of this work, see Marriott (2013).

${ }^{8}$ See Piper (1999: 219).

${ }^{9}$ My technical term for such interventions is "social opening."
} 
enough; for others, a little time and repetition will make racist jokes incompatible with their core commitments. And this is a direct result of their disavowal in response to Piper's social intervention.

Art historian Grant Kester writes of Piper's work:

When we encounter new experiences we undergo a transformation, only to gradually recohere around this transformed identity in anticipation of encounters yet to come. The extent to which we are willing to allow these experiences to touch us and to reconfigure our subsequent interactions with others varies from person to person. Piper's performances and installations provide a mise-en-scène designed to encourage such transformations. (2013: 77)

"My Calling (Card) \#1" is designed to elicit the knee-jerk defensive rationalizations and stop them in their tracks via the presence of Piper herself - the one who, in calling on this person and creating a social opening, made herself present as a black woman: "My purpose is to transform the viewer psychologically, by presenting him or her with an unavoidable concrete reality that cuts through the defensive rationalizations by which we insulate ourselves against the facts of our political responsibility" (Piper 1999: 234).

Another artist whose work focuses on social and personal transformation is Stephen Willats. ${ }^{10}$ In a work entitled Brentford Towers, Willats collaborated with residents of a West London apartment complex composed of large uniform beige towers described as "monumental objects" that "seemed to deny the complexity of people's lives within it" (Willats and Ginsborg 2008). Willats thought that this affected the residents' sense of community by affecting their

\footnotetext{
${ }^{10}$ For discussion of Willats and awesomeness, see Riggle (2017b), pp. 188-189.
} 
visibility to one another as individuals rather than as little more than "tower resident." Much of Willats' work seeks to engage people in ways that construct or elicit individuality in a way that promotes community: "My work engages the audience in a new way of encountering art in society. I am not talking about a compliance, but something more active, a mutual understanding, an interaction between people - similar to the dynamic image of the homeostat where all the parts of the network are equal and equally linked."

Willats met with fifteen of the individual residents to discuss their living spaces. He asked them to choose a meaningful object from their homes and discussed the importance of this object to them. They then discussed how it relates to something outside of the residential tower that the resident can see from their balcony or window. Willats used this information to create a visual artwork that displayed images of the resident, the tower, the interior object, and the exterior object, with lines connecting each and a quote from the resident about his or her life at Brentford Towers: "I need to be out there sometimes. It gives me a taste of what I need, just to get in contact with the elements. I like the wind blowing in my face. It makes me feel so much freer.” Every two days over a month a new work was displayed on a new floor of the tower, starting from the ground and moving up until they reached the top. The result is what Willats describes as a "sculpture in time moving up through the tower," breaking out spire-like through the top of the tower while representationally (through the displayed works) connected to cultural life outside. This created a new tower, in this case one that was "based on the personal conceptualizations of the tenants, of their daily lives within the building rather than the conceptualizations of architects and planners." This creates a symbolic sense of collective ownership of this new "conceptual" tower, a sense of collective ownership of space meant to enrich the sense of community among the residents. 
Willats draws attention to the difficulties of "presenting oneself" in certain conditions, and uses various methods of interpersonal connection - photography, discussion, use of space, meaningful attachment, public display— to spur and further such expression. Again this fits the scheme of transformative expression. Roughly, prior to engaging with Willats's work, the residents of Brentford Towers were disinclined to engage with the tower community. After engaging with Willats's work, engaging with the community was among the things they cared about. And this new preference was a result of expressing themselves as individuals-in-acommunity through Willats's work.

Some artists focus on individual transformative expression, or artworks as social interventions that target individuals as such, though often with larger social transformation in mind. But creative acts that aim at transformative expression can directly target person-types and groups - and doing so can institute social change.

Consider the norms governing a "person in public" or governing what it is to be a "citizen" in a certain nation. Such a person is governed largely by what Iris Murdoch calls "ordinary public reasons" (1970: 41). They do what "a member of the public" does. The traits and skills one needs to be a person-in-public are neither individualizing nor (normally) partly constitutive of our individual core commitments. Furthermore, the norms that determine what it is to be a person in public are standardly underwritten by broader social, cultural, and political structures. One tactic of social change focuses on getting the "person-in-public" or the "citizen" or other such person-type to transformatively express herself as that type, so as to change the character of the type itself, and to thereby change the character of citizenship.

For an illustration of this, consider Antanas Mockus, who was a math and philosophy professor, served as president of the National University of Colombia, held two terms as mayor 
of Bogotá (1995-7, 2001-3), and was nearly the president of Colombia. Mockus became the mayor of Bogotá in 1995, a time when the city suffered enormously. Pedestrian deaths soared, caused by chaotic traffic and little respect for the rules of the road. Violent late-night fights broke out regularly, accompanied by high rates of homicide. There was corruption at every level of governance. $^{12}$

The public citizen of Bogotá circa 1993, or at least one widely accepted type of public citizen then, preferred not to observe municipal laws or norms of public respect and order, and generally looked out for himself. This was true of people all throughout all levels of the city's organization, from everyday citizens, to traffic police, businesspeople, and lawmakers.

Bogotá was in need of serious change, but no one knew what to do, and nothing seemed to work. Mockus was especially willing to try anything. He also had almost no experience in politics, and was known for his brazen and unusual leadership of the National University. ${ }^{13}$ One of his first projects as mayor was to don a superhero costume with a large yellow $C$ on the chest, which stood for "Super Citizen." A film crew followed him around as he roamed the streets picking up garbage. Mockus also issued 350,000 colorful thumbs-up and thumbs-down cards to be used by drivers. Those breaking or observing the traffic rules could face scores thumbs-down or thumbs-up signs popping out of car windows.

Mockus suspected that Bogotáns would be more responsive to social stigma and collective action than to tickets and fines. The traffic police were deeply corrupt, which was a major cause of so much disorder in the city. Mockus fired them and replaced them with thousands of mimes.

\footnotetext{
${ }^{12}$ For discussion of Mockus in the context of being 'awesome' see Riggle (2017b) pp. 56-59.

${ }^{13}$ He resigned in 1993 after he mooned a group of rioting students who refused to listen to administration leaders at an assembly. He promptly ran for mayor.
} 
The mimes ran around the city mocking people who violated traffic rules, littered, fought, jaywalked, and so on. When someone did the right thing — crossed in the crosswalk, stopped at the light, threw garbage in the garbage can — the mimes banded together to create celebratory parades and scenes of spontaneous joy. Citizens became witness and participant to these scenes of mockery and praise, joining in on and encouraging the civic fun. Mockus' experiments in transformative civic expression worked; traffic deaths dropped significantly, drivers began to observe the traffic rules, and late-night violence declined (among other things). Mockus had the creative insight to construct situations where people were encouraged to express themselves as citizens in a new way—one that could (and would) transform what it is to be a citizen in Bogotá. ${ }^{14}$

These examples show that participatory art calls on us to be playful, self-reflective, exploratory or adventurous, spontaneous, open-minded, to engage in make-believe, be creative, imaginative, or engage in exploratory dialogue with strangers (among other things). What these activities have in common is that they bear a certain relation to our core commitments: they distance us from our core commitments in a way that allows for transformative expression. ${ }^{15}$

So what makes an artwork transformatively expressive? One option is to say that a work is transformatively expressive iff it causes transformative expressions in participants. However, it is too demanding of these works to require success in changing people's core commitments. A

${ }^{14}$ Bogotá's famous "comeback" is still precarious. In 2011 the New York Times reported a return of corruption and traffic chaos. See Romero (2011).

${ }^{15}$ Some philosophers have made use of the "distancing" feature of make-believe. For an account of action by ideal that does so, see Velleman (2006). For a discussion of, and alternative to, this account, see Riggle (2017a). 
nice chat with a few strangers in a museum might affect my core commitments — get me to question them, reflect upon them, imagine having different ones or restructuring them — but it probably won't change them permanently. I would have to remain inspired by the work and act on that inspiration. And whether I can depends on so many factors-social, political, economic, personal. As a result, the causal proposal does not adequately capture failures of uptake. Suppose Piper's work never actually transforms anyone because her participants turn out to be too defensive, stubborn, or mean. In that case the causal model would count Piper's work as a failure insofar as she aimed to create a transformatively expressive work. But that's the wrong result. The failure is due to the participants, not Piper.

A better option is to say that a work is transformative iff it invites transformative expression. How can a work do that? A work can invite transformative expression by inviting a certain kind of uptake in participants, namely, engagement with the work through the kinds of actions the work requires. On this model, Piper's "guerrilla performance" is a transformatively expressive work in virtue of its inviting the kind of engagement that transformative expression requires. Insofar as Piper's participants fail to take up her artistic invitations, any fault lies with them. So a work is transformatively expressive in virtue of the kind of activity it invites - the kind that is unified by its distancing relation to our core commitments-whether or not it actually transforms anyone. For such a work to fail as a work of transformative expression, it must fail to invite the kind of activity it is designed to invite.

As our examples show, not all works are transformatively expressive in the same way. We can categorize different kinds of transformatively expressive artworks according to the kind of transformation the work aims to foster. 
Replacement: The work is designed to replace at least one core commitment with another. Debord's artistic and political aspirations often suggest this approach.

Introduction: The work is designed to introduce a new core commitment. Willats's works, especially Brentford Towers, aims to cultivate a new commitment for the communitybuilding character of individual expression.

Elimination: The work is designed to eliminate a core commitment. Piper's "My Calling (Card) \#1" might introduce a new commitment, but it could succeed without doing so. A more fundamental aim is to rid people of the comfort they feel with racist comradery. Structure: The work is designed to restructure commitments. This can happen in two ways: Core Restructuring: Core commitments are reordered in a transformative way. Peripheral Restructuring: Peripheral commitments are made core. Whether core structural change is, strictly speaking, transformative expression depends on how the pretransformation commitments fail to endorse the actions endorsed post-transformation. Suppose I have a core preference ranking of food: (1) red meat, (2) poultry, (3) fish, (4) grains, (5) vegetables. On this ranking, I genuinely love vegetables-I don't have a mere peripheral preference for them. However, whenever meat is available—red, poultry, or fish-I will choose it over grains and vegetables. There's a holistic sense in which my choosing vegetables is not endorsed by my core preferences: When all my preferences are taken into account, eating vegetables is generally not what I will do. But suppose one night a brilliant friend cooks me the best vegetarian meal of my life — one that changes my sense of possibility for eating vegetarian. It's not enough to convert me; I retain all of my core food preferences. However, the meal succeeds in restructuring them: Vegetables and grains 
now come first and second respectively, and I almost always choose them over meat. This restructuring is likely to result in robustly different patterns of action when it comes to food. Group Transformation: The work is designed to cause a group of people to share commitments, where the pre-transformed group exhibits a plurality of commitments and is transformed into a homogeneity. This can be done in positive (Mockus) and negative ways through various combinations of the above.

Of course, some works are more complex or dynamic and involve multiple kinds of transformative expression. For "Documenta 12," Chinese artist Ai Weiwei created "Fairytale" (2007). He flew 1,001 Chinese citizens to Kassel to spend time in a European city, explore the art, and interact with German residents. His goal, as stated in an interview about the work, was "[t]o let them look at each other; to let them have an imagination about each other; to have romance and fantasies about each other" (dmovies.net 2013). A work this open-ended can be transformatively expressive in any of the ways detailed here.

Although it is illuminating to understand this avant-garde tradition in terms of transformative expression, it would be a mistake to think that this exhausts its interest and value. Despite the avant-garde's emphasis on transformation, these works often do far more than that; and those that are not transformative might succeed in other ways. In this, transformatively expressive art has much in common with religious and public art that uses aesthetic techniques and designs to attract, transform, and commune. As Western institutions secularized and museum and gallery practices ascended to promote and support the "fine arts," these expressive practices emerged in other ways with things like social protest music, memorial art, and mural and street 
art—practices that flourished outside of artworld confines. ${ }^{16}$ One way to think about participatory art is as the artworld-sanctioned secularization and pluralization of expressive community building.

\section{Aesthetic Value and Action}

By the late twentieth century, the philosophical and artworld understanding of art had shifted so far away from its expressive, communal role that French curator and writer Nicolas Bourriaud, an early theorist of and advocate for the participatory or (as he called it) "relational" shift in art, could write:

Today, [art] history seems to have taken a new turn ... artistic practice is now focused upon the sphere of inter-human relations, as illustrated by artistic activities that have been in progress since the early 1990s. So the artist sets his sights more and more clearly on the relations that his work will create among his public, and on the invention of models of sociability ... Meetings, encounters, events, various types of collaboration between people, games, festivals, and places of conviviality, in a word all manner of encounter and relational invention thus represent, today, aesthetic objects likely to be looked at as such ..." (1998: 28-9)

But what conceptual resources do we have for thinking that the works considered here have aesthetic value? They don't fit common ways of thinking about art and aesthetic value: They

${ }^{16}$ See Wolterstorff (2015); also see Riggle (2010). 
involve social interactions and processes, many of which do not or even could not exist in a museum or gallery. Many of the best works are not visually or aurally pleasing, if only because there is little to contemplatively view or hear. And relatedly, their effects are often not traditional aesthetic excitements, thrills, or the sense of calm or wonder familiar from many good artworks. These works focus on transformatively expressive actions with the hope of deepening connections, enriching community, and cultivating individuality, mutual understanding, and interpersonal appreciation.

To be clear, this is a question about the aesthetic value of these works, not about their artistic value. Artistic value is one thing, aesthetic value another. Lots of non-art can possess aesthetic value: sunsets, people, flowers, natural sounds, landscapes, animals, waves, skies, succulents, stars, rocks, seashells, coral, etc. Some artworks have pro tanto aesthetic merit but lack all-things-considered artistic value: for example, some film critics argue that Terrence Mallick's later films are beautiful but defective films. Furthermore, and this is the main point, something's artistic value might have nothing to do with its aesthetic value, whether or not it possesses such: John Cage's 4'33," Duchamp's Fountain, Walter de Maria's "Vertical Earth Kilometer." $" 17$

I do not doubt that the socially engaged works considered here have artistic value- -they are good artworks. ${ }^{18}$ The difficulty in properly understanding these works concerns the thought that they have aesthetic value. Indeed, they are not just artworks with social or ethical intent and

${ }^{17}$ At least, the burden of proof is on those who deny this claim. For support of the view that artistic value is a kind of aesthetic value, see Shelley (2003) and Lopes (2011). For responses to Lopes, see Hanson (2013) and Huddleston (2012).

${ }^{18}$ For a take on what their artistic value consists in, see Simoniti (2018). 
effect; some of the best of them are beautiful. They are "aesthetic objects likely to be looked at as such." The Situationists explicitly sought this "new beauty": "The new beauty will be the situation, that is, temporary and lived." 19

So here's the difficulty: how can we say that these are aesthetically good, even beautiful, artworks when their value lies primarily in their transformatively expressive character? That might confer artistic value, but how might it confer aesthetic value? How can we capture this "new beauty"?

It's not obvious, and at first blush traditional ways of thinking about aesthetic value are of little help. When we ask what aesthetic value is, there are two questions we might be asking. If we are asking what makes gracefulness, elegance, sleekness, or smoothness aesthetic values, we might be granting that they are values and asking what qualifies each as aesthetic (the demarcation question) or we might be granting that they are aesthetic values and asking what their value consists in (the normative question). ${ }^{20}$

A traditional response to the demarcation question is "formalism," or the view that strictly aesthetic value lies in certain properties that supervene on formal or "configurational" properties: The elegance of a sculpture supervenes on its shape; the warmth and softness of a painting

19 “La poếsie a épuisé ses derniers prestiges formels. Au-delà de l'esthétique, elle est toute dans le pouvoir des hommes sur leurs aventures. La poésie se lit sur les visages. Il est donc urgent de créer des visages nouveaux. La poếsie est dans la forme des villes. Nous allons donc en construire de bouleversantes. La beautế nouvelle sera DE SITUATION, c'est-ạ̀-dire provisoire et vếcue." "Réponse à̀ une enquête du groupe surréaliste belge" ("Quel sens donnez-vous au mot 'poésie'?," 1954). This is from the Letterist International, the ideologically similar group that immediately preceded the Situationists.

${ }^{20}$ See Lopes (2018), pp. 41-43. 
supervenes on the paint hues and the lack of definition in the lines. The traditional response to the normative question is "hedonism," or the view that aesthetic value bears a constitutive relation to pleasure. But what are the aesthetically relevant configurational properties of, for example, Piper's "My Calling (Card) \#1"? There are some, to be sure-e.g. the aesthetic properties of the card that Piper designed and passed out — but they do not capture the aesthetic value of the performance. Nor does a focus on pleasure seem apt here. Piper's actions are occasioned by social injustice and they are intended to confront, challenge, and transform.

It is no surprise, then, that there is a strong inclination to think about the value of these works in ethical terms. Grant Kester understands them in terms of the "creative orchestration of dialogical exchange" (2013: 189), where dialogical exchange "requires that we strive to acknowledge the specific identity of our interlocutors and conceive of them not simply as subjects on whose behalf we might act but as co-participants in the transformation of both self and society" (2013: 79). Kester's discussion and analysis of these socially oriented artworks is extremely valuable, but the same question arises: What exactly is "aesthetic" about the "creative orchestration" of dialogical exchange? And how do we unpack that metaphor? Interpersonal recognition for the sake of positive personal and social transformation is something whose value we should understand in ethical and political terms. Kester notes the strain on our traditional understanding of art and the aesthetic: “There is potentially productive terrain here for an expanded analysis of the aesthetic" (2013: 189). But, again, what could that "expanded analysis" be?

Art historian and critic Claire Bishop makes a similar point when she notes that these works don't sit comfortably in either category of the aesthetic or the ethical: 
contemporary art's :social turn" not only designates an orientation towards concrete goals in art, but also the critical perception that these are more substantial, "real", and important than artistic experiences. At the same time, these perceived social achievements are never compared with actual (and innovative) social projects taking place outside the realm of art. (Bishop 2012: 19)

Critics who set their sights on such works tend to use sociological and ethical categories like empathy, identification, community, social and personal transformation. But they do so while insisting that these works are art and so ought to be evaluated as such rather than as social or political initiatives intended to bolster empathy, community, social transformation, and so on. If we focus on what seems to make these works important - their "concrete goals" for personal and social change - then why not critically compare them with innovative social projects in general? With social or municipal programs, non-profit initiatives, or legislation?

Kester's and Bishop's remarks suggest the challenge: find a way of thinking about aesthetic value that (1) makes sense of the aesthetic value of transformatively expressive works; (2) does so in a way that captures the thought that the aesthetic character of these works is ethically significant; yet (3) justifies the critical impulse to compare these works to other items of aesthetic value. ${ }^{21}$

${ }^{21}$ Bishop addresses the issue, but her suggestive proposal is underdeveloped. She rejects understanding such works in ethical or political terms on the grounds that doing so "fails to accommodate the aesthetic or to understand it as an autonomous realm of experience" (2012: 40). She associates a concern with ethics and politics with terms like "social obligation," "super ego," "guilt," "selfsuppression," and "social consensus." And she contrasts this with the thought that we find a certain joy in acting on uninhibited desire. She favors thinking about participatory works (the good ones at least) 
A move in the right direction comes from art historian Sarah Hegenbart, who proposes a "virtue account" of participatory art: "Whereas Socrates elicits a refinement of the virtues through the rational activity of critical thinking, the [participatory] artist prepares a platform for the refinement of the virtues through aesthetic engagement" (Hegenbart 2016). What Hegenbart has in mind with "aesthetic engagement" are the creative and imaginative skills required to constitute the "meaning" of the artwork as intended by the artist (pp. 333-4). To make this concrete, consider Brentford Towers. Willats's intention was, in large part, to create a "conceptual" tower through the expressive participation of, and collaboration with, the tower residents. To participate in the creation and continued existence of this tower, the residents had to open themselves up to Willats and their fellow tower residents and contemplate and express their individuality, reflecting on and explaining décor choices, considering their visual perspective from the tower on the outside world. They also had to exercise their appreciative skills when the diagrams were displayed, interact with one another about the creation and presence of the work, and so on.

Hegenbart proposes that we understand the aesthetic value of such works by connecting these creative and expressive activities to virtue. She adopts a welcoming theory of virtue according to which virtues are "excellent skills that enable us to overcome ... novel

as works that do not shape or suppress desire but rather liberate it, or accommodate it in raw form, and thereby offer such pleasure. Bishop seems to think that there is personal and communal value in works that function this way, but she it is not clear about what the value amounts to. And by emphasizing individual "enjoyment" and the "autonomy" of the aesthetic, she seems to rely on hedonism and formalism (or at least on thoughts that tend to motivate those views) and to reject Kester's call for an "expanded analysis of the aesthetic." As a result, it is not clear how her view meets the challenge. 
challenges." ${ }^{22}$ And using this theory, she puts the aesthetic value of participatory works down to a connection between ethical and aesthetic virtue: "If we practice creative responses to new and unexpected situations in the aesthetic realm, this might improve our ability to respond creatively to new situations in the moral realm. So creativity may enable us to react reliably across different moral and aesthetic situations" (2016: 335).

The idea is that participatory works have aesthetic value because they cultivate aesthetic virtues. And aesthetic virtues, in turn, are important for the cultivation and practice of moral virtue. But does this answer the challenge? It seems not. While Hegenbart offers a way of making sense of (1) and (2), her view does not seem to justify the critical impulse to compare these works to other works of aesthetic value. Any project aimed at cultivating aesthetic virtues - art classes, dance contests, after-school arts programs, and indeed style and cooking shows - would seem to make fair comparisons.

While I don't doubt that participatory works could make participants more virtuous in some sense, there is a deeper problem with understanding the value of participatory works in such terms. If we employ a moral concept of virtue, then the theory will be too narrow to capture the range of ways these works engage participants in ethically salient activities. As we noted above, many participatory works are intent on encouraging, among other things, play, expressive freedom, adventurousness, and self-exploration through novel, challenging, or creative action. These activities implicate us in interpersonal relations that can ground community and that are normatively structured in substantive ways, but which escape traditional ways of thinking about morality. But if we employ a broader concept of virtue — as something like human excellence-

\footnotetext{
${ }^{22}$ She takes inspiration from Julie Annas' account of virtue developed in Annas (2011).
} 
then we will misconstrue the value of these works. They are valuable, ethically and aesthetically, independently of any connection they might have to the good of certain cultivated dispositions that (partly) constitute human excellence. Indeed, our discussion thus far shows that part of their value lies precisely in distancing us from, or breaking us out of, our dispositions.

Let's make this more concrete by focusing on one of the relevant action-types-play. Play is good, and part of its value involves the kind of volitional openness that lends itself to transformative expression. The ability to play is central to the cultivation, expression, and mutual appreciation of individuality; it allows us to explore different ways of cultivating ourselves-our values, ideals, projects, and so on; and it allows us to creatively riff on, or break out of, social norms and everyday routines to express our individuality to others, so that we can connect with one another as individuals, not merely as people playing social roles or as subjects who merit respect. Being playful is part of what it is to be an individual..$^{23}$

But we can be playful without playfulness featuring among our core commitments. The ability to play does not require that we be a playful person. The capacity to play is a kind of everpresent foil against or alongside our core commitments. In other words, to be playful is not necessarily to have a commitment or disposition to play. It's to have an ability to freely disengage from your commitments, dispositions, preferences, and so on.

To illustrate this further, let's return to style-makeover Dagny. Imagine that Dagny is motivated in part by a playful spirit. We don't have to think that Dagny becomes a more virtuous person in order to think that her playfully adopting a new style is ethically and aesthetically significant. Cultivating and expressing our individuality plays an important role in interpersonal

${ }^{23}$ For discussion of this in the context of a theory of social virtue see Riggle (2017b). 
relations. Dagny's new style will create social openings for those who are acquainted with her; inspire others in their own style activity; create new opportunities for gifting, exploration, and exchange. Her new way of expressing her individuality will be a focus of her own creative efforts, seeping into a number of other ways she has of expressing herself, but in a way that binds her to others through shared expressive and appreciative activity. And all of these activities are subject to interpersonal normative structure that determines the appropriateness of various modes of response to Dagny and her new style. Focusing on the question of whether Dagny's playful change makes her a more excellent person obscures the personal and communal import of her efforts, and threatens to shift focus away from the tentative, experimental, exploratory character of these activities.

When we play, we engage what I call our "pure individuality," which forms the core of what I think of more generally as our individuality. Our pure individuality is our basic capacity to act in a volitionally open way - to imitate, be spontaneous, adventurous, expressive, and so on. These activities allow us to reflect on, refine, and cultivate our core commitments; and they help us change or abandon them. Our individuality gains definition as we cultivate ways of playing, exploring, etc. that we value - we cultivate not just the basic ability to value and appreciate, but a refined sense of care and love; not just the basic ability to spontaneously imagine, but the capacity for make-believe and storytelling; not just the basic ability to joke and laugh, but a sense of humor; and so on. In other words, we use our pure individuality to sculpt a self. It is through these characteristically aesthetic activities - play, adventure, experimentation, spontaneity, and so on - that we shape, cultivate, and reshape ourselves as individuals. In this way, acting from our pure individuality, and cultivating the ability to do so, is ethically significant. 
So in what sense, if at all, do these actions have aesthetic value? One approach is to try to tie them to traditional ways of thinking about aesthetic value. We already saw that hedonism and formalism have difficulty with transformatively expressive works. But another thought behind such theories is that it is only when we experience configurational properties in a certain way, "disinterestedly," that we can experience the aesthetic properties that supervene on them and so properly experience the pleasures they occasion. Disinterest is the glue that binds formalism and hedonism: To experience the grace in a speech, the elegance of a sculpture's shape, the sleekness of a coat, one must experience the speech, the sculpture, the coat in such a way that one's various motives and commitments do not get in the way. For example, if you disagree with the content of the speech, are too focused on how the sculpture will make you money or will socially impress, or find umbrellas useless because you live in a desert-your focus on these features threatens to prevent you from taking pleasure in the grace, elegance, or sleekness. Following this way of thinking, we might say that it is only when we take up the invitations of transformatively expressive art-distancing ourselves from or bracketing our core commitments, i.e. "disinterestedly" as it were - that are we in a position to be affected by those works as intended. Where certain properties of works invite us to see or hear or more generally experience in certain aesthetic ways, so other properties invite us to act in certain aesthetic ways. But in both cases a kind of "disinterest" is important. This could justify the critical impulse to place participatory art in an evaluative comparison class with other works of aesthetic value.

Another approach abandons these ways of thinking about aesthetic value..$^{24}$ Instead of thinking of aesthetic value as the power to please, we might think of it as the power to put us in a

${ }^{24}$ For a critique of disinterest, see Riggle (2016); for a critic of hedonism, see Lopes (2018); see also Van der Berg forthcoming. 
more volitionally open state. On this view, the aesthetic value of transformatively expressive art lies in its engaging us in distancing activities, inviting us to freely disengage from our core commitments. What makes these works aesthetically valuable is not that they have certain configurational properties on which aesthetic properties supervene; rather, it's that they invite aesthetic action. Where some works invite us to see, hear, or experience certain things, others invite us to do certain things. And when what they invite us to do has aesthetic value, we can say that such works are good artworks and are good in virtue of their aesthetic value.

\section{Conclusions}

Thinking about aesthetic value and action in this way helps us answer the question we posed at the outset: If a transformatively expressive action is not endorsed by, and is in some cases incompatible with, one's core commitments, then how can we say that it is self-expressive? In what sense is a "self" being expressed, even though we aren't expressing our core commitments? We might even worry that we cannot say that the action is one's own or a product of selfgovernment and not alienated, forced, or just something that happens or is caused by the artwork.

Our discussion suggests that there's a part of the self we can tap into even when (but not always when) we have lost touch with our core commitments: In freely distancing ourselves from our commitments, we tap into another part of ourselves. When we express our pure individuality, we express deep features of ourselves in ways that might fill gaps in, or run counter to, our cultivated sense of self but precisely because of that might be liberating, even transformative. We might come to see a new side of ourselves or of life. This amounts to a counterexample to various partial theories of authenticity and autonomy that require the 
expression of self-constituting dispositions. If what I have suggested is right, then that part of the self is aesthetic. If we want to understand human action, then we cannot ignore the aesthetic.

Of course, there is much more to explore and pin down along these lines. But the thought that there is a deep connection between aesthetic value, self-realization, and volitionally-open action is not without precedent. Friedrich Schiller thought that really great art would have this kind of distancing effect on us: through witnessing genuine art we enter a volitional state in which we "shall with equal ease turn to seriousness or to play, to repose or to movement, to compliance or to resistance." Schiller thought that doing so makes us more social and egalitarian individuals, equipped to engage in activities that allow us to present, recognize, and appreciate our own and each other's individuality. Schiller called this special state "play."

Schiller also tells us, "A person only plays when they are a person in the full sense of the word, and they are fully a person only when they play." As strange as that may sound, maybe there's something to it. There is a tight connection between the pure individuality and a capacity that has as good a claim as anything else to being that which grounds our personhood, namely, our capacity for love. If we are so attached to our core commitments that we lose touch with our pure individuality — unable to play, pretend, be spontaneous, adventurous, and so on — then we also lose access to the forms of interaction and mutual appreciation that depend on it. The early Situationists emphasized this connection: "[T]his striving for playful creativity must be extended to all known forms of human relationships, so as to influence, for example, the historical evolution of sentiments like friendship and love" (Debord 2006a [1957]: 40). Schiller himself thinks that being in touch with aesthetic value, i.e. that which causes us to play, is the only way we can really be free, and that this freedom is what makes us truly social. That we all attain such a state is a hope embodied in so many transformatively expressive works - the hope that, as we 
cultivate ourselves and each other through aesthetic acts and objects, we will find new and exciting ways of being and bonding. ${ }^{26,27}$

\section{References}

Annas, J. 2011. Intelligent Virtue. Oxford: Oxford University Press.

Bishop, C. 2012. Artificial Hells. London: Verso.

Bourriaud, N. 1998. Relational Aesthetics. Dijon: Les presses du réel.

Calhoun, C. 2009. "What Good Is Commitment?" Ethics 119(4): 613-41.

Carter, R. 2008. The Japanese Arts and Self-Cultivation. New York: SUNY Press.

Chung, J. (2018). “Moral Cultivation: Japanese Gardens, Personal Ideals, and Ecological Citizenship." Journal of Aesthetics and Art Criticism 76(4): 507-18.

Clark, T., C. Gray, D. Nicholson-Smith, and C. Radcliffe. n.d. "The Revolution of Modern Art and the Modern Art of Revolution." < https://www.cddc.vt.edu/sionline/si/modernart.html>

Debord, G. 2006a [1957]. "Report on the Construction of Situations and on the International Situationist Tendency’s Conditions of Organization and Action.” In K. Knabb (ed. and trans.), International Situationalist Anthology, 25-43. Berkeley, CA: Bureau of Public Secrets.

${ }^{26}$ For a detailed interpretation of Schiller's theory of aesthetic value and its connection to individual and political freedom see our co-authored paper Riggle and Matherne (2018).

${ }^{27}$ Thanks to Antonia Peacocke and Eric Carter for helpful comments. Thanks also to audiences at the Chapel Hill Workshop on Transformative Experience and the APA Pre-Conference on Themes in Transformative Experience. 
Debord, G. 2006b [1958]. "Preliminary Problems in Constructing a Situation.” In K. Knabb (ed. and trans.), International Situationalist Anthology, 49-51). Berkeley, CA: Bureau of Public Secrets.

Debord, G. 2006c [1958]. “Theses on Cultural Revolution.” In K. Knabb (ed. and trans.), International Situationalist Anthology, 53-4). Berkeley, CA: Bureau of Public Secrets. dmovies.net. 2013. "Ai Weiwei, Fairytale (2007), interview at Documenta 12." $<\mathrm{https}: / /$ vimeo.com/68202707>

Frankfurt, H. G. 1971. "Freedom of the Will and the Concept of a Person." Journal of Philosophy 68(1): 5-20.

Hanson L. 2013. "The Reality of (Non-Aesthetic) Artistic Value.” Philisophical Quarterly 63(252): 492-508.

Hegenbart, S. 2016. “The Participatory Art Museum: Approached from a Philosophical Perspective.” Royal Institute of Philosophy Supplement 79: 319-39.

Huddleston, Andrew. 2012. "In Defense of Artistic Value." Philosophical Quarterly 62(249): $705-14$.

Kester, G. H. 2013. Conversation Pieces: Community and Communication in Modern Art. Berkeley, CA: University of California Press.

Lopes, D. M. 2011. “The Myth Of (Non-Aesthetic) Artistic Value.” Philosophical Quarterly 61(244): 518-36.

Lopes, D.B. 2018. Being for Beauty: Aesthetic Agency and Value. Oxford: Oxford University Press.

Magritte, R. (ed.) 1954. “Quel sens donnez-vous au mot ‘poésie'?” La carte d'après nature (January). 
Marriott, D. 2013. “On Racial Etiquette: Adrian Piper's My Calling (Cards).” Postmodern Culture 24(1).

Murdoch, I. 1970. The Sovereignty of Good. Abingdon: Routledge.

Paul, L.A. 2014. Transformative Experience, Oxford: Oxford University Press.

Piper, A. 1999. Out of Order, Out of Sight. Cambridge, MA: MIT Press.

Riggle, N. 2010. "Street Art: The Transfiguration of the Commonplaces.” Journal of Aesthetics and Art Criticism 68(3): 243-57.

Riggle, N. 2016. “On the Interest in Beauty and Disinterest.” Philosophers' Imprint 16(1): 114.

Riggle, N. 2017a. "Personal Ideals as Metaphors." Journal of the American Philosophical Association 3(3): 265-83.

Riggle, N. 2017b. On Being Awesome: A Unified Theory of How Not to Suck. London: Penguin Random House.

Riggle, N., and S. Matherne. 2018. "Schiller on Freedom and Aesthetic Value, Parts 1 \& 2," British Journal of Aesthetics, forthcoming

Romero, S. 2011. “Columbia’s Resurgent Capital Backslides Amid Crime and Congestion.” New York Times (May 5).

Saltz, J. 2010. "How I Made an Artwork Cry.” New York Magazine (February 7).

Schiller, F. 1993. Letters on the Aesthetic Education of Man in Essays: Friedrich Schiller, eds. Walter Hinderer and Daniel O. Dahlstrom, trans. Elizabeth M. Wilkinson and L.A. Willoughby. New York: Continuum: 86-178.

Shelley, J. 2003. "The Problem of Non-Perceptual Art.” British Journal of Aesthetics 43(4): $363-78$. 
Simoniti, V. 2018. “Assessing Socially Engaged Art.” Journal of Aesthetics and Art Criticism 76(1), 71-82.

Van der Berg, S. forthcoming. "Aesthetic Hedonism and Its Critics," Philosophy Compass.

Velleman, J. D. 2006. “Motivation by Ideal.” In J. D. Velleman (ed.), Self to Self, 312-29. Cambridge: Cambridge University Press.

Walden, K. 2015. “Art and Moral Revolution.” Journal of Aesthetics and Art Criticism 73(3): $283-95$.

Willats, S. (producer), and C. Ginsborg (director) 2008. A State of Agreement [motion picture]. England: Arts Council England.

Wolterstorff, N. (2015). Art Rethought: The Social Practices of Art. Oxford: Oxford University Press. 